\title{
Pelaksanaan Haji Di Luar Bulan Dzulhijjah
}

\author{
Fajar Syarif \\ Institut Ilmu Al-Qur'an (IIQ) Jakarta \\ fajarsyarif@iiq.ac.id
}

\begin{abstract}
This research has proven that the time of implementation of performing hajj that is exist now is raw so it is impossible to establish the the hajj performing beyond the predetermined time. It is based on the proposition exist, not only in the Qur'an but also in Hadith. In accordance with the object of study, the type of this study is a research of library (library research). Therefore, during the assessment, the argument that supports this paper and understanding construction process, are taken from books or representative and relevant research with this study object.
\end{abstract}

Keywords: worship, pilgrimage, postulate

\begin{abstract}
Abstrak
Penelitian ini membuktikan bahwa waktu pelaksanaan ibadah haji yang ada sekarang ini bersifat baku sehingga tidak mungkin ditetapkan pelaksanaa ibadah haji di luar waktu yang telah ditetapkan. Hal ini didasarkan pada berbagai dalil yang ada, baik yang terdapat dalam al-Qur'an dan al-Hadits. Sesuai dengan objek kajiannya, penelitian ini termasuk dalam jenis penelitian kepustakaan (library research). Karena itu, selama pengkajian berlangsung, argumentasi yang mendukung tulisan ini dan proses konstruksi pemahaman yang dilalui, diambil dari buku-buku atau penelitian yang representative dan relevan dengan objek studi ini.
\end{abstract}

Kata kunci : ibadah, haji, dalil

\section{Pendahuluan}

Beribadah haji adalah puncak pengharapan setiap muslim dalam menjalankan ajaran Islam karena dengan melaksanakannya, berarti seorang muslim telah memenuhi rukun Islam yang kelima di samping adanya nilai tersendiri yang dimiliki oleh ibadah haji bagi sebagian orang. Namun, tidak

FOKUS : Jurnal Kajian Keislaman dan Kemasyarakatan Vol. 5, No. 1, 2020

LPPM Institut Agama Islam Negeri (IAIN) Curup - Bengkulu

p-ISSN 2548-334X, e-ISSN 2548-3358

DOI: $10.29240 /$ jf.v5i1.1127 
semua harapan tersebut berjalan mulus dan sesuai dengan keinginan setiap muslim. Sebab perlu disadari bahwa ibadah haji bukanlah ibadah yang dalam melakukannya semata-mata berkaitan dengan dirinya sendiri. Ibadah haji tidak seperti shalat ataupun puasa yang dalam melakukannya tidak perlu berhubungan dengan pihak lain. Ibadah haji juga ada kaitannya dengan masalah sosial, budaya, ekonomi dan politik. Dengan demikian, ibadah haji memiliki dimensi yang sangat luas.

Karena dimensi yang sangat luas itu, terkadang sering muncul masalah-masalah yang berkaitan dengan pelaksanaan ibadaha haji seperti pembatasan kuota bagi setiap negara oleh pemerintah Saudi, paspor hijau sampai masalah tragedi kemanusiaan yang terjadi di tanah suci.

Masalah-masalah yang timbul akibat dampak tidak tertatanya secara rapi sistem manajemen dan birokrasi dapat diatasi dengan perbaikan dalam bidang tersebut. Akan tetapi, dari berbagai masalah yang muncul, ada yang sangat menarik perhatian penulis yaitu tentang tragedi kemanusiaan yang terjadi selama ini di tanah suci.

Sebagai misal, pada tahun 1990 musibah melanda jama'ah haji di terowongan Mina. Sebanyak 643 orang Indonesia meninggal dunia yang merupakan bagian dari korban sebanyak 1.426 orang tewas dalam musibah di terowongan al-Mualisin, Haratul Lisan. Musibah ini terjadi saat 5000 orang dari berbagai negara yang akan dan telah melakukan pelemparan jumrah terjebak dan berdesak-desakan di terowongan yang ketika itu hanya berkapasitas 1.000 orang. Keadaan ini diperparah oleh sistem ventilasi rusak yang membuat panik jama'ah yang berada di terowongan ${ }^{1}$.

Musibah ini kembali terjadi pada tahun 1994 saat jama'ah melempar jumrah, sebanyak 270 orang meninggal dunia terinjak-injak. Penyebabnya adalah ratusan ribu orang yang tidak memperdulikan instruksi dan petunjuk yang sudah diberikan oleh muthawwif (pemandu haji). Mereka berdesakan dan berebut melaksanakan pelemparan jumrah pada hari Nafar Awal.

Musibah yang sama terulang kembali pada tahun 1998 dimana sebanyak 118 orang meninggal dunia. Pada musim haji tahun 2003-2004 jama'ah yang meninggal sekitar 244 jama'ah haji yang terinjak-injak ketika

${ }^{1}$ S. Satya Dharma, Haji Kita; Fakta dan Problem Penyelengaran Haji Di Indonesia 1999-2000, (Jakarta: Asosiasi Wartawan Muslim Indonesia, 2000), Cet I, hlm. 10 
melempar jumrah ${ }^{2}$. Dan yang terakhir yaitu pada tahun 2015, insiden jatuhnya crane di kawasan Masjidil Haram dengan korban wafat sebanyak 107 jama'ah dan juga terjadi saling injak dan dorong antar ribuan jama'ah haji di jalanan sempit dekat area tenda di lapangan Mina, setelah ibadah melempar jumrah. Sedikitnya 220 jama'ah tewas ${ }^{3}$.

Dari berbagai macam problem itu, mulai dari masalah pemabatasan kuota oleh pemerintah Arab Saudi yang sebenarnya tidak menyelesaikan persoalan karena bertentangan dengan hak umat Islam untuk melaksanakan salah satu rukun Islam tersebut sampai pada terjadinya berbagai musibah yang dialami jama'ah haji yang diakibatkan mungkin karena keteledoran jama'ah itu sendiri ataupun dikarenakan memang tempat yang sudah tidak memungkinkan untuk menghindari bencana tersebut sehingga musibah yang semacam itu terjadi hampir setiap tahun, muncul beberapa ide yang menawarkan solusi untuk menghindarkan umat Islam dari berbagai kesulitan dan musibah semacam itu.

Diantara ide yang muncul sebagai solusi adalah dalam hal waktu penyelenggaraan ibadah haji yang hendaknya tidak dibatasi pada lima hari saja yaitu hanya pada tanggal 9-13 Dzulhijjah, gagasan seperti ini antara lain dilontarkan oleh seorang purnawiran jendral dari Mesir bernama Muhammad $\mathrm{Shibl}^{4}$. Di Indonesia, gagasan ini dilontarkan oleh Masdar Farid Mas'udi ${ }^{5}$.

Menurut pendapat ini, ibadah haji itu dapat dilakukan pada tanggal kapan saja sepanjang tiga bulan itu. Sebab, sepanjang tiga bulan itu adalah waktu keabsahan untuk berhaji dan berarti juga keabsahan untuk wukuf, karena inti dari haji adalah wukuf. Dengan demikian, kalau satu bulan ada empat minggu dan satu prosesi haji diandaikan berlangsung selama sepuluh hari, maka selama satu bulan bisa berlangsung tiga kali shift atau tiga kali angkatan haji. Jadi, pada bulan Syawal 3 shift, bulan Dzulqa'dah 3 shift dan bulan Dzulhijjah 3 shift.

\footnotetext{
${ }^{2}$ Kompas, Kolom Fokus, Musibah-musibah itu, Edisi Sabtu, 7-2-2004, hlm. 43

${ }^{3}$ https://www.wartainfo.com/2015/09/tragedi-mina-arab-saudi-ratusan-jamaah-hajimenjadi-korban.html. Diakses pada 7 Agustus 2016

${ }^{4}$ Abdul Mahdi bin Abdul Qadir bin Abdul Hadi, al-Radd 'ala Liwa' Muhammad Syibl fi Inkar Yaum 'Arafah, (Cairo: Ruz Yusuf, Majalah al-Azhar, 1420 H), hlm. 105

${ }^{5}$ Masdar F. Mas'udi, Kolom Kajian, Bisa Berhaji dalam Waktu Tiga Bulan, Indo Pos, Edisi minggu, 18-1-2004, hlm. 4
} 
Dengan demikian, dalam tiga bulan itu akan ada 12 shift. Andai saja dalam satu shift bisa dilakukan untuk satu juta orang, maka dalam setahun akan ada 12 juta orang yang berhaji. Dan itu akan dilakukan dengan aman, rileks, dan khusyu karena hanya ada satu juta orang dalam sekali angkatan. Dengan begitu, penyelenggaraan haji juga akan lebih manageable, baik oleh pemerintah yang memberangkatkan maupun pemerintah Saudi, disamping dapat mengurangi berbagai musibah yang selalu menimpa umat Islam ketika melaksanakan ibadah haji.

Adapun argument yang mendasari pemikiran bahwa haj dapat diperpanjang atau dimelarkan waktunya, antara lain ${ }^{6}$;

1. Karena tingkat masyaqqat atau kesulitan yang sudah sangat luar biasa, yang saat ini dialami para hujjaj. Sebagai misal, pada saat melempar jumrah. Ketika itu, ada saja jama'ah haji yang meninggal dunia akibat terinjak-injak karena begitu sesaknya, bahkan kadang-kadang yang meninggal itu sampai puluhan dan hal itu terus terjadi dari tahun ke tahun. Dari sini timbul pertanyaan, misalnya apakah ibadah haji itu sudah menjadi semacam arena "pembantaian"? Sebab, nyatanya haji telah menimbulkan berbagai kesulitan yang sangat luar biasa, bahkan korban jiwa yang tidak sedikit. Padahal, hal itu bertentangan dengan prinsip Islam yaitu prinsip al-Din Yusr (agama itu mudah dan memberikan kemudahan). Juga hal itu bertentangan dengan prinsip al-Qur'an surat alHajj ayat 78:

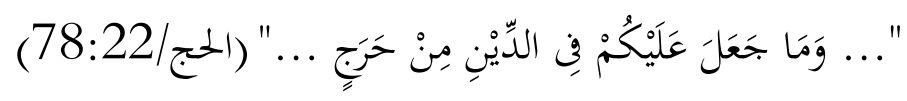

“...Allah tidak menjadikan kesulitan kepadamu dalam beragama...” (alHajj/22:78)

2. Waktu haji itu tidak sesempit yang kita pahami selama ini. Waktu haji bukanlah hanya berlangsung pada tanggal 9, 10, 11, dan 12 Dzulhijjah atau dilonggarkan sampai 13 Dzulhijjah (5 hari). Sebab dalam al-Qur'an surat al-Baqarah ayat 197, Allah swt berfirman;

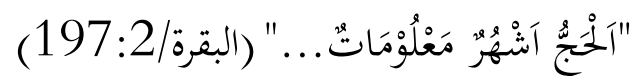

\footnotetext{
${ }^{6}$ Masdar F. Mas'udi, Kolom Kajian, Bisa Berhaji dalam Waktu Tiga Bulan, Indo Pos, Edisi minggu, 18-1-2004, hlm. 4
} 
"Waktu haji itu adalah beberapa bulan" (al-Baqarah/2:197)

Dalam ayat itu ditegaskan dengan sangat jelas bahwa waktu haji ini beberapa bulan, bukan beberapa hari. Adapun sekarang ini dipersempit menjadi lima hari itu karena disebabkan praktek Rasulullah saw yang berhaji hanya sekali dan kebetulan hari-hari itu (9-13 Dzulhijjah). Tetapi hal itu bukan berarti bahwa haji hanya sah pada hari-hari itu saja. Karena jika dibatasi pada hari-hari tersebut, maka akan bertentangan dengan ayat di atas. Dari sini dapat dipahami bahwa apa yang dilakukan oleh Nabi Muhammad saw dengan melaksanakan haji pada hari-hari itu hanya merupakan ikhtiyar Nabi Muhammad saw saja dari beberapa bulan waktu haji, bukan wahyu dari Allah swt. karena itu, kemungkinan ada waktu-waktu lain untuk melaksanakan haji selain waktu yang sudah kita kenal ${ }^{7}$. Dengan demikian, menurut pendapat ini, haji Rasulullah saw yang hanya sekali dalam hidupnya tidak bisa dijadikan dasar bahwa haji di luar hari-hari tersebut tidak sah. Apalagi tidak ada satu nash pun, baik ayat al-Qur'an dan hadits Nabi Muhammad saw, bahkan yang dha'if sekalipun, yang menyatakan dengan jelas bahwa menunaikan manasik haji di luar hari-hari ke-8 sampai dengan ke-13 Dzulhijjah tidak sah hukumnya. Sedangkan hadits yang menyatakan bahwa puncak haji adalah wukuf di Arafah itu hanya berbicara soal aktivitas, bukan waktu sahnya haji karena tidak dijelaskan pada hari dan tanggal berapa wukuf di Arafah itu dilaksanakan. Jadi intinya, haji adalah wukuf di Arafah. Sebab jika dipahami bahwa puncak ibadah haji adalah wukuf di Arafah dan harus tanggal 9 Dzulhijjah, maka itu berarti sebagai mengorbankan (ilgha') nash al-Qur'an yang sharih tentang haji yang beberapa bulan itu ${ }^{8}$.

Dengan demikian, menurut pendapat ini, sebenarnya haji itu dapat dilakukan kapan saja dalam beberapa bulan yang telah diteantukan yaitu bulan Syawal, Dzulqa'dah dan Dzulhijjah selama pelaksanaan wukufnya dilaksanakan di Arafah. Di sisi lain, berbagai kejadian dan musibah yang hampir setiap tahun menimpa para hujjaj bisa dihindari seminimal mungkin.

\footnotetext{
${ }^{7}$ Abdul Mahdi bin Abdul Qadir bin Abdul Hadi, al-Radd 'ala Liwa' Muhammad Syibl fi Inkar Yaum 'Arafah, (Cairo: Ruz Yusuf, Majalah al-Azhar, 1420 H), hlm. 106

${ }^{8}$ Abdul Mahdi bin Abdul Qadir bin Abdul Hadi, al-Radd 'ala Liwa' Muhammad Syibl fi Inkar Yaum 'Arafah, (Cairo: Ruz Yusuf, Majalah al-Azhar, 1420 H), hlm. 109
} 
Akan tetapi, ide ini ternyata bertentangan dengan pendapat para ulama yang selama ini menyatakan bahwa ibadah haji harus dilakukan pada hari-hari tertentu. Mereka berargumen antara lain dengan surat al-Baqarah ayat 189 dan 197 yang telah disebutkan sebelumnya dengan diperkuat hadits Nabi Muhammad saw yang menyatakan bahwa inti haji adalah wukuf di Arafah. Untuk waktu wukufnya, para ulama menyatakan bahwa wukuf itu harus dilaksanakan pada tanggal 9 Dzulhijjah sesuai dengan waktu wukuf yang pernah dilakukan Nabi Muhammad saw. Di samping itu, Nabi Muhammad saw juga memerintahkan kita untuk mengambil manasik dari beliau dan perintah tersebut juga mencakup dalam waktu pelaksanaan wukuf. Selain kedua hadits ini, ada juga beberapa hadits lain, yang meskipun tidak menunjukkan secara langsung, namun dapat memberikan isyarat kalau dalam pelaksanaan ibadah haji itu ada waktu-waktu tertentu yang tidak boleh dilanggar.

Dari pertentangan ini, penulis ingin mengkaji lebih mendalam tentang mungkin tidaknya dilakukan penambahan waktu ibadah haji dari yang selama ini ada.

\section{Fiqh Haji Di Luar Bulan Zulhijjah}

Ibadah haji termasuk ibadah pokok yang menjadi salah satu rukun Islam yang lima. Sebagai rukun Islam, hukum melaksanakan ibadah haji adalah wajib berdasarkan al-Quran, sunnah dan ijma'. Seseorang yang sudah memenuhi syarat untuk melaksanakan ibadah haji tidak dapat menghindar dari kewajiban itu dengan alasan apapun.

Karena sudah menjadi suatu kewajiban, maka umat Islam berusaha untuk melaksanakan ibadah haji tersebut dengan sebaik-baiknya. Apalagi, tidak ada balasan bagi haji yang mabrur kecuali surga.

Namun dalam pelaksanaannya ibadah haji ini, terkadang muncul berbagai hal yang pada awalnya dapat dilaksanakan dengan mudah, kini terasa sulit atau tidak dapat dilaksanakan sepenuhnya. Sebagai misal, dalam hadis dinyatakan bahwa waktu melempar jumrah adalah setelah matahari tergelincir ke barat Akan tetapi, karena semakin padatnya jama'ah haji, 
menjadikan ketentuan ini sangat sulit untuk dilaksanakan sesuai dengan petunjuk hadis tersebut ${ }^{9}$.

Berdasarkan berbagai pertimbangan, para ulama membolehkan melontar jumrah sebelum matahari tergelincir ke barat di saat pelaksanaan haji. ${ }^{10}$ Demikian juga dalam ketentuan miqat makani berdasarkan hadis Nabi Saw telah ditetapkan miqat makani bagi mereka yang melaksanakan haji dari segenap penjuru, tempat atau negara. Akan tetapi, karena perkembangan dan perubahan situasi, maka ketentuan miqat tersebut sulit atau tidak dapat diikuti sepenuhnya, termasuk oleh jama'ah haji dari Indonesia. Sehubungan dengan hal tersebut, Majelis Ulama Indonesia (MUI) telah mengambil langkah-langkah untuk mengantisipasinya dengan mengeluarkan fatwa bahwa bagi jama'ah haji Indonesia boleh memulai ihram dengan miqat di Jeddah, Dzulkhulaifah dan bandar udara king Abdul Aziz. ${ }^{11}$

Berangkat dari sini pula, ketika terjadi tragedi dalam pelemparan jumrah 'aqabah yang menelan banyak korban, muncul ide agar waktu pelaksanaan haji dikembangkan lagi dari yang ada sekarang. Hal ini bertujuan agar tidak terjadi lagi tragedi yang memilukan tersebut. Ide ini memakai argumen bahwa seharusnya yang menjadi patokan dalam penentuan waktu pelaksanaan ibadah haji adalah surat al-Baqarah ayat 197, "waktu haji adalah beberapa bulan yang telah diketahui", dan juga karena adanya kesulitan luar biasa yang saat ini dialami para jamaah haji ${ }^{12}$.

Ide ini memunculkan reaksi yang sangat keras dari berbagai kalangan karena dianggap merubah aturan yang sudah baku dan menyalahi ketentuan yang sudah ada. Ide ini mengisyaratkan keharusan adanya perubahan dan diberlakukannya konsep ijtihad dalam masalah waktu pelaksanaan haji karena waktu pelaksanaan haji yang sekarang ini dianggap tidak relevan lagi dan bertentangan dengan kemaslahatan umat

281.

${ }^{9}$ Umar Shihab, Kontekstualitas al-Quran, (Jakarta: Penamadani, 2004), cet. П, hlm.

10 Pendapat ini didasarkan pada dua pendapat fuqaha tabi'in, yaitu Atha' dan Thawus. Lihat: Yusuf al- Qardhawi, 'Awamil al-Sa'ah wa al-Muru'ah fi al-Syari'ah alIslamiyah, (Kairo: Dar al-Shahwah, 1985), hlm.156-157.

11 Lihat, MUI, Kumpulan Fatwa Majelis Ulama Indonesia, (Jakarta: Pustaka Panjimas, 1984), hlm. 29-33.

${ }^{12}$ Masdar F. Mas'udi, Bisa Berhaji Dalam Waktu Tiga Bulan, Indo Pos. kolom kajian. Edisi minggu, 18-1-2004. hlm. 4. 
Dalam pandangan penulis, untuk menentukan bisa tidaknya waktu pelaksanaan ibadah haji dikembangkan lagi supaya sesuai dengan perkembangan zaman sehingga tidak menimbulkan kesulitan, itu dapat dikaji dari sudut pandang ketentuan hukum waktu pelaksanaan haji itu sendiri. Apakah ketentuan hukum ini masuk dalam kategori masalah yang sudah baku ataukah memang masih dapat berubah demi kemaslahatan.

Dalam kajian ushul fiqh, ketentuan-ketentuan hukum itu ada yang bersifat tauqifi dan taufiqi. Makna tauqifi di sini adalah segala sesuatu yang telah didatangkan oleh Syari' dan tidak ada seorangpun yang berhak untuk menambah atau mengurangi sesuatu yang telah ditentukan tersebut, di samping masalah ini juga tidak menjadi lapangan ijtihad ${ }^{13}$ dan tidak boleh dikaji hanya berdasarkan maslahat ${ }^{14}$. Dengan kata lain, tauqifi adalah suatu ketentuan yang tidak boleh dilakukan diluar dari apa yang telah dicontohkan oleh Syari' -yang dalam hal ini adalah Nabi saw- terutama dalam hal-hal yang hanya dilakukan sekali saja oleh Nabi saw. Sedangkan makna taufiqi adalah segala sesuatu yang dicapai melalui jalan ijtihad sehingga pada masa yang akan datangpun sesuatu tersebut dapat diijtihadi kembali dengan bentuk ijtihad yang lain ${ }^{15}$.

Di antara hal-hal yang masuk dalam kategori tauqifi adalah masalahmasalah yang bersifat ta'abbudiyyah, yaitu ketentuan hukum dari nash Quran dan Hadits yang harus diterima apa adanya oleh manusia dan dilaksanakan sesuai dengan ketentuan hukum tersebut tanpa boleh ditawar-tawar serta tanpa memerlukan penalaran karena bersifat absolut di mana manusia hanya dituntut untuk melaksanakannya sesuai dengan nash ${ }^{16}$.

Segala masalah yang berkaitan dengan ta'abbudi yang di antara cakupannya adalah masalah-masalah ibadah mahdhah dan hal-hal yang dharuriyyat, ini hukum-hukumnya tidak mungkin diubah karena pada

\footnotetext{
${ }^{13}$ Qutub Musthafa Sanu, Mu'jam Mushthalah Ushul al-Fiqh, (Beirut: Dar al-Fikr, 2000), cet I, hlm. 152.

${ }^{14}$ Muhammad Hisyam al-Ayyubi, al-ljtihad wa Muqtadhayat al-Ashr, (Beirut: Dar al-Fikr, t.th), hlm. 211.

${ }^{15}$ Qutub Musthafa Sanu, Mu'jam Mushthalah Ushul al-Fiqh, hlm. 151

${ }^{16}$ Abdul Aziz Dahlan (ct, al), Ensiklopedi Hukum Islam (Jakarta: Ichtiar Baru Van Hoeve, 1996), jilid V, hlm. 1723.
} 
asalnya hukum tersebut tidak didasarkan pada kemaslahatan ${ }^{17}$. Hal ini disebabkan karena ibadah merupakan hak khusus bagi Allah swt sehingga bentuk dan tata cara pelaksanaannya pun sepenuhnya dilakukan sesuai dengan kehendak dan petunjuk Allah swt serta penjelasan dari rasul-Nya yang telah menjabarkan secara rinci dan sempurna bentuk dan tata cara pelaksanaan ibadah tersebut sehingga tidak boleh ditambah, dikurangi dan atau diubah ${ }^{18}$.

Jika pintu maslahat dibuka dalam bidang ibadah, maka akan berakibat kepada perubahan warna dan syi'ar agama dengan beragamnya bentuk ibadah sesuai dengan maslahat yang diyakininya masing-masing. Lebih jauh lagi, hal ini akan berakibat pada munculnya keinginan manusia untuk menciptakan dan mengembangkan bentuk-bentuk ibadah sesuai dengan الاصل : seleranya ${ }^{19}$. Maka dari itu, dalam masalah ibadah berlaku kaidah fiqh (dalam ibadah, pada dasarnya manusia hanya mengikuti petunjuk yang diberikan). Hal ini berarti bahwa dalam hal-hal ibadah kita tidak boleh berbuat sesuatu diluar petunjuk yang sudah ditetapkan ${ }^{20}$.

Sebagai misal tentang jumlah raka'at shalat lima waktu. Dalam hal ini, kita tidak diperkenankan untuk menambah ataupun mengurangi ketentuan jumlah rakaat shalat lima waktu karena Rasulullah saw sendiri melaksanakan shalat lima waktu dengan jumlah raka'at yang seperti sekarang ini dan tidak pernah sekalipun beliau melaksanakan shalat dengan jumlah raka'at yang berbeda dengan ketentuan yang ada (kecuali dalam shalat qashar). Ini menunjukkan kalau masalah jumlah raka'at dalam shalat itu bersifat baku dan tidak dapat diubah (tauqifi). Sifat baku ini semakin kuat dengan didukung oleh sabda Rasulullah saw yang pernah memerintahkan para sahabatnya untuk meniru cara shalat beliau yang di dalamnya mencakup jumlah bilangan raka'at. Selain itu, seandainya jumlah bilangan raka'at itu dapat diubah, tentu Rasulullah saw tidak akan menambah satu raka'at lagi

${ }^{17}$ Muhammad Salam Madkur, al-Madkhal al-Fiqh al-Islami, (Cairo: Maktabah alQawwiyyah li al-Nasyr wa al-Thaba'ah, 1964), hlm. 102.

${ }_{18}$ Amir Syarifuddin, Garis-Garis Besar Fiqh, (Jakarta: Prenada Media, 2003), hlm. 13.

${ }^{19}$ Husni Thoyar, Ta'abbudi dan Ta'aqquli dalam Pandangan al-Syatibi, dalam jurnal Kordinat, volume: VI, no: 2, Oktober 2004, hlm. 3.

${ }^{20}$ Amir Syarifuddin, Garis-Garis Besar Fiqh, hlm. 13 
untuk menggenapkan jumlah raka'atya ketika dalam suatu waktu beliau diberitahu oleh para sahabat kalau shalatnya itu kurang satu raka'at. Dengan demikian, jumlah raka'at shalat lima waktu itu bersifat permanen karena itu masuk dalam kategori tauqifi.

Sedangkan hal yang termasuk dalam kategori taufiqi di sini adalah masalah- masalah yang dapat diijtihadi dikarenakan berdasarkan dalil-dalil nash yang atau masalah yang tidak ada nashnya sama sekali, ${ }^{21}$ atau bisa juga masalah yang dibangun berdasarkan kemaslahatan yang umumnya terdapat dalam bidang muamalah atau bidang kemasyarakatan. ${ }^{22}$

Masalah yang dibangun berdasarkan kemaslahatan ini mengandung unsur dinamis yang mempunyai kemampuan untuk dapat menampung berbagai perkembangan dan perubahan. Unsur dinamis ini, karena di samping watak dalilnya yang berupa prinsip-prinsip umum dan terbuka untuk menerima berbagai penafsiran sesuai dengan ketentuan tafsir, juga yang paling menonjol adalah adanya unsur illat dan tujuan hukumnya (maqashid al-syari'ah). Masalah-masalah seperti ini dikenal dengan ajaran yang bersifat ta'aqquli karena sifat rasionalitasnya. ${ }^{23}$

Najmuddin al-Thufi, sebagaimana dikutip oleh Husein Hamid Hassan, menyatakan bahwa lapangan penetapan maslahat hanya berlaku dalam bidang mu'ammalat dan adat, bukan dalam bidang ibadah. Lebih lanjut al-Thufi memandang bahwa maslahat dapat digunakan sebagai dalil syara' dalam bidang mu'ammalat dan adat. Sedangkan dalam bidang ibadah dan muqaddarat, maslahat tidak dapat dipakai sebagai dalil, tetapi cukup hanya dengan mengikuti yang ada dalam nash, ijma' dan dalil-dalil syara'. Al-Thufi menyatakan bahwa jika hukum syara' itu termasuk dalam bidang ibadah dan muqaddarat, maka yang dipegangi adalah nash, ijma' dan dalildalil lainnya. Sedangkan dalam bidang umum yang diperhatikan adalah maslahat ${ }^{24}$.

\footnotetext{
${ }^{21}$ Wahbah al-Zuhaili, Ushul al-Fiqh al-Islami, (Beirut: Dar al-Fikr, 1996), Cet. VI, Juz II, hlm. 1053.

${ }^{22}$ Muhammad Hisyam al-Ayyubi, al-ljtihad wa Muqtadhayat al-Ashr, hlm. 211.

${ }^{23}$ Husni Thoyar, Ta'abbudi dan Ta'aqquli dalam Pandangan al-Syatibi, hlm. 3.

${ }^{24}$ Husein Hamid Hassan, Nadzariyyat al-Maslahah fi al-Fiqh al-Islami, (Beirut: Dar al-Nahdhah al-Arabiyah, 1971), hlm. 534..
} 
Dalam bidang ibadah, seseorang tidak boleh membuat aturan kecuali sesuai dengan aturan yang telah disyari'atkan oleh Alah swt, atau sebagaimana yang telah diungkapkan oleh al-Syatibi bahwa dalam bidang ibadah kita harus kembali kepada apa yang telah ditentukan oleh Syari' ${ }^{25}$.

Jadi, aturan-aturan hukum dalam Islam yang bersifat ta'abbudt menjadi sah dan baik karena semata-mata adanya eksistensi kebajikan yang terkandung di dalamnya, bukan karena rasionalitasnya ${ }^{26}$.

Dengan demikian jika ditinjau dari konsep tauqifi dan taufiqi' ini, nampaknya sulit bekali untuk mengatakan bahwa waktu pelaksanaan haji dapat dikembangkan lagi dikarenakan waktu yang ada sekarang ini tidak memberikan kemaslahatan bagi para jama'ah. Hal ini disebabkan karena ibadah haji adalah ibadah mahdhah yang dalam penentuan waktu pelaksanaannya itu bersifat ta'abbbudi karena bidang ibadah merupakan hak khusus bagi Syari'. Kita tidak mungkin mengetahui hak-haknya dalam menentukan cara, waktu dan tempat ibadah. Oleh karena itu, seorang hamba hanya melaksanakan ibadah sesuai dengan apa yang telah ditetapkan ${ }^{27}$.

Sifat ta'abbudi dalam penentuan waktu haji ini dapat diketahui dari sisi bahwa makna illat yang terkandung dalam penentuan waktu pelaksanaan haji itu tidak dapat diketahui oleh akal. Sebab kita tidak mengetahui secara pasti mengapa wukuf di Arafah harus tanggal 9 Dzulhijjah. Atau ketika dalam masalah shalat misalnya, kita tidak mengetahui mengapa shalat maghrib harus tiga raka'at dan mengapa shalat yang tanpa berwudhu' itu dihukumi tidak sah. Oleh sebab illatnya tidak dapat diketahui karena tidak dapat direntangkan dengan ditambah atau diganti sehingga berakibat pada tidak berlakunya qiyas ${ }^{28}$ maka, waktu pelaksanaan ibadah haji tidak dapat dikembangkan. Ia bersifat terbatas, sesuai dengan lahiriyah teks dan harus terikat dengan teks tersebut ${ }^{29}$. Dari sini disimpulkan bahwa tidak dapat terjadi pengembangan dalam waktu pelaksanaan ibadah haji.

${ }^{25}$ Abu lshaq Ibrahim al-Lakhmi al-Gharnati al-Syatibi, al-Muwafaqat fi Ushul alAhkam, ed: Sayyid Muhammad al-Hadhar Husain, (Beirut: Dar al-Fikr, t.th), juz II, hlm. 304

${ }^{26}$ Fathurrahman Djamil, Filsafat Hukum Islam, (Jakarta: Logos Wacana Ilmu, 1999), hlm. 52

${ }^{27}$ Fathurrahman Djamil, Filsafat Hukum Islam, h. 52

${ }^{28}$ Husni Thoyar, Ta'abbudi dan Ta'aqquli dalam Pandangan al-Syatibi, hlm. 7

${ }^{29}$ Husni Thoyar, Ta'abbudi dan Ta'aqquli dalam Pandangan al-Syatibi, hlm. 11 
Sifat keterbatasan atau kebakuan waktu pelaksanaan haji juga dapat dilihat dan diperkuat dari sisi keberadaan dalil itu sendiri. Sebab, jika dilihat secara lebih mendalam, maka dalil pelaksanaan waktu haji itu tidak dapat hanya ditentulkan oleh surat al-Baqarah 197 semata. Sebab kenyataannya masih ada beberapa ayat lain yang secara tersirat memberikan informasi tentang adanya batasan waktu pelaksanaan haji, seperti ayat 196 dari surat alBaqarah yang berbicara tentang haji tamattu': "maka bagi siapa yang ingin mengerjakan 'Umrah sebelum Haji (di dalam bulan Haji), (wajiblah ia menyembelih) korban yang mudah didapat". Ayat ini mengindikasikan adanya waktu tertentu untuk pelaksanaan haji. Sebab, seandainya haji dapat dilaksanakan kapan saja selama tiga bulan, tentu perintah untuk menyembelih korban bagi orang yang melaksanakan haji tamattu' itu tidak bersifat wajib dan tidak ada artinya, karena haji dapat dilaksanakan pada awal atau akhir waktu dari tiga bulan. Namun kenyataannya tidak demikian.

Demikian juga dengan ayat 203 dari surat al-Baqarah, "dan berdzikirlah (dengan menyebut nama Allah) dalam beberapa hari yang berbilang". Ayat ini menunjukkan kalau perintah berdzikir dalam ibadah haji itu hanya dilakukan beberapa hari saja, bukan beberapa bulan.

Tentang ayat ini, para ulama sepakat kalau yang dimaksud ayyam ma'dudat di sini adalah hari tasyriq. Memang ada yang menyatakan kalau maksud ayyam ma'dudat adalah ayyum al-basyr (hari kiamat), sebagaimana diriwayatkan oleh al-Tsa'labi dari al-Mahdi ${ }^{30}$. Namun, menurut al-Qurthubi, penafsiran riwayat seperti ini mengandung dua kemungkinan. Kemungkinan pertama adalah bahwa terjadi kesalahan dalam membaca teks yang dilakukan oleh al-Tsa'labi, dan kemungkinan kedua adalah bahwa yang dimaksud sebenarnya adalah ayyam al- 'asyr (hari kesepuluh), bukan ayyam al-hasyr' . Akan tetapi, bisa jadi riwayat tersebut adalah benar. Hanya maksud penafsiran tersebut tidaklah ditujukan pada avat 197 surat al-Baqarah, tapi pada ayat 24 surat Ali Imran yang berbicara tentang kaum Yahudi yang menyatakan bahwa ketika di neraka, mereka itu hanya disiksa beberapa hari

\footnotetext{
${ }^{30}$ Muhammad bin Ahmad bin Abu Bakar al-Farah al-Qurtubi, al-Jami' li Ahkam alQur'an, (Beirut: Dar al-Sya'b, 1372 H), juz III, hlm. 1

${ }^{31}$ Muhammad bin Ahmad bin Abu Bakar al-Farah al-Qurtubi, al-Jami' li Ahkam alQur'an, juz III, hlm. 1
} 
saja (ayyam ma'dudat) ${ }^{32}$. Padahal mereka akan berada di dalamnya selamanya. Maka dari itu, ada kemungkinan juga kalau penafsiran ayyam albasyr di atas ditujukan pada ayat ini.

Demikian juga dengan surat al-Hajj ayat 28 yang berbunyi, "dan supaya mereka menyebut nama Allah pada hari yang telah dimaklumi atas rezeki yang Allah telah berikan kepada mereka berupa binatang ternak" (QS. 22:28). Ayat ini menyatakan bahwa waktu penyembelihan hewan ternak (qurban) oleh jama'ah haji itu dilakukan pada waktu tertentu di mana waktu penyembelihan tersebut sudah dikenal oleh Nabi saw dan para sahabatnya sejak zaman dulu, yaitu tanggal 10,11, 12 dan 13 Dzulhijjah. Maka dari itu, para ulama menafsiri kata "ayyam ma'lumat" dengan hari-hari kurban. $^{33}$

Selain ayat-ayat ini, ada juga beberapa hadits yang mengindikasikin kalau proses ibadah haji itu hanya dilakukan pada waktu-waktu tertentu saja, yaitu dari tanggal 9 sampai 13 Dzulhijjah. Seperti hadits yang menyatakan bahwa "barang siapa yang datang pada malam hari (mabit di Muzdalifah) sebelum terbit fajar, maka sesungguhnya ia telah mendapatkan haji" dimana redaksi ini menunjukkan adanya pembatasan waktu tertentu untuk melaksanakan haji. Sebab, seandainya seluruh waktu yang tercakup dalam asyhurun ma'lumat itu dapat dijadikan waktu haji, tentu Nabi saw tidak akan membatasinya dengan mengatakan "sebelum terbit fajar", "maka sesungguhnya ia telah mendapatkan haji". Karena orang yang tidak dapat datang ke Muzdalifah sebelum terbit fajar pada tanggal sepuluh Dzulhijjah setelah sebelumnya berada di Arafah- dapat melaksanakannya pada hari yang lain selama masih dalam bulan haji. Namun ternyata tidak demikian. Sebab orang yang tidak dapat wukuf di Arafah harus mengqadha' hajinya pada tahun berikutnya. Selain itu, seandainya ibadah haji dapat dilaksanakan kapan saja selain tiga bulan, maka batasan "sebelum terbit fajar" itu tidak memberikan manfa'at apa-apa.

Dan juga hadits Nabi saw yang berisi tentang jawaban beliau terhadap pertanyaan yang dilontarkan oleh salah seorang sahabat tentang sah tidaknya

\footnotetext{
${ }^{32}$ Muhammad bin Ahmad bin Abu Bakar al-Farah al-Qurtubi, al-Jami' li Ahkam alQur'an, juz II, hlm. 11

${ }_{33}^{33}$ Muhammad bin Jarir bin Yaitd bin Khalid al-Thabari, Tafsir al-Thabari, (Beirut: Dar al-Fikr, 1405 H), Juz II, hlm. 304.
} 
ibadah haji yang dilakukannya. Dalam hal ini, Nabi saw mengatakan, "barang siapa yang menyaksikan shalat kita itu dan berhenti bersama kita hingga berangkat maka hajinya telah sempurna." Seandainya wukuf di Arafah dan mabit di Muzdalifah dapat dilakukan pada hari yang lain selama selama masa bulan-bulan haji, tentu Rasulullah saw tidak akan mengatakan hal ini karena beliau tahu bahwa apa yang telah dilakukannya itu (yaitu wukuf di Arafah) dapat dilaksanakan di lain waktu. Namun kenyataannya tidak demikian. Sebab pernyataannya ini menunjukkan kalau orang yang melaksanakan haji pada waktu yang tidak sama dengan waktu pelaksanaan haji beliau, maka hajinya itu tidak sah.

Selain itu, dalam sejarah hidup Rasulullah saw, terhitung beliau melaksanakan umrah sebanyak 3 kali, seluruhnya pada bulan Dzulqa'dah ${ }^{34}$. Pertama pada masa perjanjian Hudaibiyah tahun 6 Hijriyah. Kedua, pada tahun berikutnya dan ketiga pada tahun 8 Hijriyah ketika beliau membebaskan kota Mekkah ${ }^{35}$. Dari sini, kita mengetahui kalau Rasulullah saw hanya melaksanakan umrah beberapa kali dalam bulan Dzulqa'dah yang termasuk asyhurum ma'lumat. Namun beliau tidak sekalian melakukan haji, padahal haji pahalanya jauh lebih besar dari pada hanya sekedar umrah. Realita ini menunjukkan bahwa sebenarnya haji memiliki waktu tertentu untuk berwukuf dan saat beliau melalaikan umrah, waktu wukuf itu sendiri belum datang sehingga beliaupun tidak melakukan haji Sebab, kalaulah ibadah haji boleh dilakukan kapan saja selama tiga bulan, tentu saat itu Rasulullah saw akan langsung berhaji. Tapi kenyataannya tidak demikian.

Dari beberapa ayat, hadits dan bukti sejarah di atas yang walaupun tidak secara langsung menyatakan kalau haji itu harus dilaksanakan pada waktu-waktu tertentu, yang diantaranya adalah adanya keharusan wukuf pada tanggal 9 Dzulhijjah, namun dapat ditarik suatu kesimpulan kalau ketentuan waktu ibadah haji yang ada sekarang ini dilalah-nya bersifat qath'i. Ke-qathi'-an ini diperoleh dari banyaknya dalil pendukung yang saling melengkapi, yang mengisyaratkan hal tersebut. Memang jika dalildalil tersebut berdiri sendiri, mungkin kedudukan dalil-dalil tersebut adalah

\footnotetext{
${ }^{34}$ Muhammad bin Ali al-Syaukani, Nail al-Authar, (Beirut: Dar al-Khair, 1998), Cet. II, Juz IV, hlm. 590.

35 Hisyam Abu Muhammad Abdul Malik bin Hisyam al-Ma'afiri, Muskhtashar Sirah Ibnu Hisyam, (Cairo: al-Ahkam al-Tijariyah, 1999), Juz II, hlm. 64,115, dan 196
} 
sebagai dalil yang dilalah-nya bersifat zhanni. Namun karena banyaknya dalil serupa yang mengisyaratkan bahwa ibadah haji itu harus dilaksanakan pada waktu-waktu tertentu, yaitu di antaranya harus tanggal 9 Dzulhijjah sebagai hari wukuf, maka dilalah nash-nash tersebut dapat menjadi seperti mutawatir ma'nawi yang berfa'idah qath'i.

Selain itu, hal yang tidak diperhatikan oleh penggagas ide ini adalah tidak digunakannya sunnah Nabi saw sebagai hujjah secara utuh. Memang, jika diteliti secara seksama, dapat dikatakan kalau sunnah Nabi saw yang sering dilontarkan untuk menjadi dalil bagi adanya kewajiban wukuf di Arafah yang harus dilakukan pada tanggal 9 Dzulhijjah itu tidak secara jelas menunjukkan adanya suatu keharusan, karena dalam teks hadits tersebut tidak disebutkan tanggal 9 Dzulhijjah. Namun semua sunnah itu barulah sunnah yang bersifat qauliyah. Yang kurang menjadi perhatian di sini adalah berlakunya sunnah fi'liyyah sebagai sumber hukum. Kita mengetahui bahwa sunnah fi'liyyah juga merupakan bagian dari hadits Nabi saw yang dapat berfungsi sebagai penjelas, baik bagi Quran maupun bagi sunnah qauliyah itu sendiri sehingga memungkinkannya untuk dijadikan hujjah.

Sunnah fi'liyah di sini adalah perbuatan Nabi saw sendiri yang melakukan haji, di mana salah satu kegiatannya adalah melakukan wukuf di Arafah yang beliau laksanakan pada tanggal sembilan Dzulhijjah. Perbuatan beliau ini dapat menjadi penjelas bagi khittah (titah hukum) yang terdapat dalam Qur an maupun sunnah qauliyyah yang masih bersifat mujmal.

Dalam masalah ini, dalil yang masih bersifat mujmal adalah surat alBaqarah ayat 196-197, ayat 203 dan surat al-Hajj ayat 28 serta berbagai hadits yang menyatakan ketentuan waktu haji secara tersirat, sebagaiman telah disebutkan di atas. Di sini, baik Quran maupun sunnah qauliyyah sendiri tidak menunjukkan secara jelas bahwa wukuf itu harus tanggal sembilan Dzulhijjah. Namun ketika melaksanakan haji, ternyata Nabi saw melakukan wukuf pada tanggal tersebut. Dari sini para sahabat mengetahui kalau perbuatan Nabi saw ini merupakan penjelasan bagi keterangan yang terkandung dalam ayat dan hadits di atas. Hal ini dapat dilihat dari perbuatan mereka yang ketika melaksanakan ibadah haji, setelah wafatnya Nabi saw, selalu melaksanakan wukuf di Arafah pada tanggal sembilan Dzulhijjah. 
Dengan demikian, perbuatan Nabi saw ini dapat menjadi penjelas bagi keduanya $^{36}$.

Adapun bagi orang yang tidak menyaksikan perbuatan Nabi saw ini, maka secara zhahir, perbuatan itu juga dapat menjadi penjelas bagi kita karena ada kemungkinan Nabi saw telah menjelaskannya dengan ucapan namun tidak sampai kepada kita $^{37}$.

Dengan demikian dapat dikatakan kalau perbuatan Nabi saw yang melakukan haji pada waktu tertentu, yang diantaranya adalah keharusan melaksanakan wukuf di Arafah pada tanggal 9 Dzulhijjah, itu bersifat wajib karena qarinah yang ada, yaitu wukuf itu sendiri hukumnya wajib. Kepastian wajib ini juga didukung oleh pernyataan Nabi saw yang menunjukkan bahwa haji seseorang itu tidak sah kecuali setelah mabit di Muzdalifah sebelum terbit fajar. Dengan demikian, ucapan Nabi saw ini menjadi qarinah yang menunjukkan wajib bagi perbuatan Nabi saw itu sendiri.

Perbuatan Nabi saw di sini dapat dijadikan hujjah yang menunjukkan suatu kewajiban meskipun tidak dilakukan secara berulang-ulang. Karena, jika perbuatan yang menunjukkan suatu kewajiban itu harus dilakukan secara berulang-ulang, maka persyaratan seperti ini bertentangan dengan realita yang ada. Sebab kenyataannya banyak juga perbuatan Nabi saw yang dilakukan secara berulang-ulang, namun tidak menimbulkan hukum wajib, tetapi hanya sunnah saja. Sebagai misal, perbuatan Nabi saw yang melaksanakan shalat pada awal waktu. Para ulama sepakat bahwa shalat pada awal waktu hukumnya sunnah, bukan wajib, karena Nabi saw sendiri pernah melakukan shalat pada akhir waktu. Dengan demikian, suatu hukum yang tercermin atau timbul dari perbuatan Nabi saw yang berkedudukan sebagai penjelas itu tidak tergantung pada seberapa banyak Nabi saw melakukannya, akan tetapi tergantung pada hukum yang dijelaskan ${ }^{38}$.

Sedangkan jika dilihat dari konsep masyaqqat, maka musibah yang sering terjadi dalam pelaksanaan ibadah haji -seperti timbulnya korban jiwa

${ }^{36}$ Muhammad Sulaiman al-Asyqar, Af'al al-Rasul wa Dilalatuha 'Ala al-Ahkam alSyar'iyyah, (Beirut: Mu'assasah al-Risalah, 1992), Cet. III, hlm. 295.

${ }^{37}$ Muhammad Sulaiman al-Asyqar, Af'al al-Rasul wa Dilalatuha 'Ala al-Ahkam alSyar'iyyah, hlm. 295

${ }^{38}$ Muhammad al-Arusi Abdul Qadir, Af'al al-Rasul wa Dilalatuha Ala al-Ahkam, (Jeddah: Dar al-Mujtami' li al-Nasr wa al-Tauzi', 1991), Cet. II, hlm. 64. 
ketika melempar jumrah disebabkan berdesak-desakkan dan bertabrakan arus antara yang menuju ke lokasi dan yang akan kembali- secara sepintas dapat digolongkan ke dalam bagian masalah yang masuk kategori dharurat yang harus memperoleh keringanan. Sebab adanya korban jiwa menandakan adanya kesulitan luar biasa yang dialami jama'ah haji dalam pelaksanaan ibadah tersebut.

Namun sebenarnya hal-hal tersebut harus diteliti kembali sebelum memasukkan musibah yang terjadi dalam ibadah haji itu ke dalam kategori masalah yang mendapat keringanan (rukhshah) sehingga konsep masyaqqat dapat diberlakukan.

Jika diteliti lebih lanjut, konsep masyaqqat itu diterapkan ketika hukum asal itu sulit sekali atau bahkan tidak dapat lagi diberlakukan. Ini berarti bahwa sebelum muncul masyaqqat yang dialami seseorang, kita mengakui keabsahan hukum asal tersebut Namun ternyata pemberi ide tentang penambahan waktu haji tidak mengakui keabsahan hukum asal tentang waktu haji yang ada sekarang ini. Hal ini dapat dilihat dari argumennya yang menyatakan bahwa sebenarnya waktu haji itu tidak sesempit yang kita pahami selama ini ${ }^{39}$. Dengan demikian, pemberi ide ini tidak dapat menerapkan konsep masyqqat untuk menguatkan argumennya.

Selain itu, seandainya konsep masyaqqat ini ingin tetap diterapkan, maka harus diperhatikan terlebih dahulu beberapa faktor yang menyebabkan terjadinya musibah tersebut. Di antara faktor-faktor tersebut adalah ${ }^{40}$ :

a. adanya pemahaman yang sempit dan cenderung skripturalis terhadap waktu-waktu yang utama (afdhaliyyat) dalam pelaksanaan melontar jumrah, padahal zaman dan situasi dan kondisi telah jauh berubah dari zaman Nabi saw.

b. ketidakpatuhan jamaah terhadap peraturan-peraturan haji yang ditetapkan oleh pemerintah Saudi dengan alasan mementingkan nilai keutamaan ibadahnya. Peraturan yang dimaksud, misalnya tentang pengaturan jadwal pelemparan batu jumrah bagi tiap-tiap negara. hlm. 16 .

${ }^{39}$ Muhammad al-Arusi Abdul Qadir, Af'al al-Rasul wa Dilalatuha Ala al-Ahkam,

${ }^{40}$ Muchlis M Hanafi, Waktu Ibadah Haji Tidak Perlu Ditinjau Kembali, (Jakarta: Majalah Islamia) thn.I, no.2, edisi. Juni-Agustus, 2004, hlm. 64. 
c. Kurangnya sosialisasi peraturan-peraturan tersebut oleh pihak penyelenggara. Sebab, peraturan-peraturan itu bagaimanapun bagusnya, pelaksanaannya tentu tidak dapat dilepaskan dari manusia-manusia yang diberi aturan-aturan itu. Dalam hal ini, aturan-aturan itu diperuntukkan sekitar dua juta orang dari berbagai bangsa, ras dan adat istiadat dengan taraf pendidikan -termasuk dibidang agama yang rata rata awan. Maka dari itu, pihak penyelenggara harus dapat benar-benar mensosialisasikan aturan tersebut

Dengan melihat berbagai faktor ini, maka dapat disimpulkan bahwa kesulitan-kesulitan jamaah haji yang menimbulkan berbagai korban jiwa itu tidak dapat digolongkan sebagai suatu kesulitan yang berpengaruh dalam meringankan suatu hukum masyaqqat bisa diterapkan. Adanya ketidakpatuhan, pemahaman yang dan kurangnya sosialisasi peraturanperaturan haji tidak dapat menjadi alasan diberlakukannya ketentuan masyaqqat yang membolehkan dikembangkannya waktu haji. Sebab suatu perbuatan yang dapat memperoleh keringanan adalah perbuatan-perbuatab yang ketika dilakukan dengan mengikuti aturan-aturan yang ada, namun tetap saja menimbulkan kesulitan.

Dalam konteks ibadah haji, pelaksanaannya tidak hanya berkaitan antara para jama'ah dangan Allah swt semata. Namun juga berkaitan dengan pemerintah Saudi yang notabane sebagai panitia penyelenggara haji. Maka dari itu, para jamaah-pun harus mengikuti aturan-aturan ada. Dengan demikian, kesulitan-kesulitan yang terjadi dikarenakan melanggar suatu ketentuan yang bertujuan untuk kemaslahatan dapat dikategorikan sebagai kesulitan yang dapat menarik kemudahan.

Adapun kesulitan lain yang dialami para jamaah haji, seperti suasana berdesak-desakkan ketika mereka bertolak dari Arafah menuju ke Muzdalifah dan Mina, sebenarnya sudah diprediksi sejak jauh hari oleh Quran sendiri. Hal ini dapat dilihat dalam firman Allah swt dalam surat al-Baqarah ayat 199:

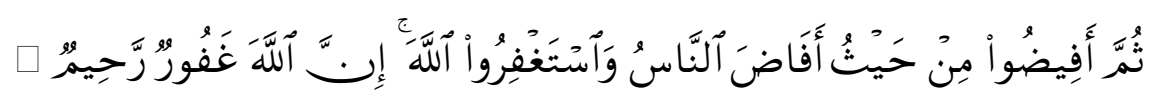

Kemudian bertolaklah kamu dari tempat bertolaknya orang-orang banyak (Arafat) dan mohonlah ampun kepada Allah; sesungguhnya 
Allah Maha Pengampun lagi Maha Penyayang. (QS. AlBaqarah/2:199)

Kata afidu di sini menggambarkan betapa saat itu akan terjadi "luapan masa yang besar" pada satu titik waktu dan tempat yang sama. Dalam mu'jam maqayis al- Lughah disebutkan bahwa akar kata fa ya dha itu menunjukkan arti pada sesuatu yang mengalir lancar, deras dan melebihi batas $^{41}$. Hal ini menunjukkan kalau kondisi pelaksanaan ibadah haji sekarang ini sudah diprediksikan sebelumnya oleh Allah swt.

Karena itu, dalam beberapa riwayat, Nabi saw menyeru kepada jama'ah haji agar menjaga ketenangan ketika bertolak dari Arafah menuju ke Muzdalifah dan Mina. Beliau mengatakan:

$$
\text { السكينة ايها الناس السكينة ايها الناس (رواه ابو داود) }
$$

Jagalah ketenangan wahai manusia, jagalah ketenangan wahai manusia"! (HR. Abu Daud)

Jadi karena kesulitan teknis telah diprediksi, maka solusi yang paling tepat adalah kembali kepada esensi ibadah itu sendiri, yaitu ketenangan. Sebab, berapapun jumlah jama'ah yang datang, namun masing-masing tidak melaksanakannya dengan tenang, maka akan tetap terjadi masyaqqat ytng serupa. Jadi teknis pelaksanaan ibadah haji yang sifatbya ijtihadi inilah yang perlu ditinjau kembali dan disesuaikan dengan keadaan, disamping keharusan adanya ketaatan jama'ah haji terhadap aturan-aturan teknis yang telah ditetapkan, bukan waktu pelaksanaannya.

Selain itu, terjadi kontradiksi dalam pemakaian argumen yang digunakan oleh penggagas ide pengembangan waktu haji. Dari dalil al-Quran surat al-Baqarah, menunjukkan kalau hukum asal waktu pelaksanaan ibadah haji adalah tiga bulan. Namun di sisi lain, penggagas memakai alasan masyaqqat untuk melegalkan penambahan waktu haji. Padahal hukum yang ditimbulkan oleh adanya masyaqqat adalah suatu hukum yang pada asalnya bukanlah hukum yang terkandung masalah yang diberi rukhshah akibat adanya

41 Ahmad Ibnu Faris, Mu'jam Maqayis al-Lughah, (Beirut: Dar al-Kutub alIlmiyyah, 1999), cet. I, juz II, h. 336.

${ }^{42}$ Sulaiman bin al-Asy'at Abu Daud al-Sajastani, Sunan Abu Daud, kitab: alManasik, bab: Daf'ah min Arafah, (Beirut: Dar al-Fikr, t.th.), juz II, hlm. 190. 
masyaqqat. Dengan kata lain, dapat dikatakan bahwa penggagas ide ini mengakui bahwa waktu haji adalah tiga bulan. Tetapi di sisi lain dia mengakui kalau waktu haji itu adalah apa yang ada sekarang ini. Hal ini dapat dilihat dari alasan masyaqqat yang diajukan sebagai argumen. Sebab dampak dari masyaqqat adalah ditetapkannya rukhsah dan rukhsah itu sendiri adalah ketetapan hukum yang berlawanan dengan dalil yang ada dikarenakan adanya halangan.

Dengan penjelasan di atas, penulis melihat bahwa ada beberapa kelemahan yang terdapat dalam gagasan pengembangan waktu pelaksanaan haji ini yang di antaranya adalah adanya penafsiran yang sangat literal dan parsial. Hal ini terlihat dari argumentasi penggagas yang hanya memakai dalil dari surat al-Baqarah ayat 197 saja. Padahal masih ada ayat-ayat lain yang mempunyai hubungan dengan penentuan waktu pelaksanaan haji, sebagaimana yang telah dijelaskan sebelumnya. Jika metode ini yang dipakai, maka akan muncul akibat yang mengesankan terjadinya pertentangan antara satu ayat dengan ayat lainnya, suatu hal yang tidak mungkin terjadi terhadap al-Qur'an. Sebab pertentangan yang ada antara satu ayat dengan ayat lainnya itu terjadi sebagai akibat dari kekurangjelian dalam memahami suatu masalah, yang mempunyai dalil dari beberapa ayat, secara utuh. Padahal jika masing-masing ayat dipahami sesuai konteks pembicaraannya, maka anggapan seperti itu tidak akan terjadi ${ }^{43}$.

Selain penafsiran literal dan parsial, penggagas ini menunjukkan adanya keengganan menggunakan hadits. Hal ini dapat dilihat dari argumentasi penggagas yang hanya menggunakan satu ayat dan hadits secara selektif untuk mendukung gagasannya, tanpa mau menyimak dengan teliti keseluruhan hadis Rasulullah saw yang berkaitan dengan pelaksanaan haji. Sekiranya penggagas mau mempertimbangkan hadits-hadits yang berkaitan dengan waktu pelaksanaan ibadah haji -baik yang mengindikasikan makna secara tersurat maupun tersirat- maka sampai pada kesimpulan bahwa haji dapat dilakukan kapan saja dalam beberapa bulan ${ }^{44}$.

Gagasan ini nampaknya berusaha untuk merekonstruksi beberapa kaidah-kaidah yang sudah ada dalam kajian ilmu ushul fiqh. Sebagai misal tentang tata cara memahami qath'i zhanni. Dalam pandangan umum, qath'i

\footnotetext{
${ }^{43}$ Abdurrahman Dahlan, Kaidah-Kaidah Penafsiran al-Qur'an, (Bandung: Mizan, 1997), cet. I, hlm. 30.

${ }^{44}$ Muchlis M Hanafi, Waktu Ibadah Haji Tidak Perlu Ditinjau Kembali, hlm. 69-70
} 
dan zhanni itu ditentukan dari nash, baik Quran maupun sunnah. Namun penggagas melihat bahwa apa yang disebut sebagai dalil qath'i adalah nilai kemaslahatan dan keadilan yang merupakan jiwa dari hukum itu sendiri. Sedangkan yang dimaksud dalil zhanni adalah keseluruhan nash, ketentuan normatif yang dapat dipergunakan untuk menterjemahkan yang qath'i (nilai kemaslahatan dan keadilan) ${ }^{45}$. Maka dari itu, penggagas berpendapat bahwa ketentuan waktu haji yang selama ini ada, dapat ditambah karena dalildalilnya bersifat zhanni dan dalil yang zhanni merupakan lapangan ijtihad.

Ide ini akan dapat menimbulkan terjadinya perubahan di segala bidang keagamaan, dengan alasan melakukan ijtihad, tanpa membedakan antara bagian yang masuk dalam kategori 'ubudiyyah dan mu'amalah. Padahal paradigma yang dianut dalam ibadah adalah ittiba' al-nash (mengikuti ketentuan nash). Hal ini sesuai dengan kaidah yang berbunyi: al-ashlu fi alibadah al-tauqif (dalam ibadah, pada dasarnya manusia hanya mengikuti petunjuk yang diberikan).

Dengan demikian, waktu pelaksanaan ibadah haji tidak dapat dikembangkan karena penetapannya berdasarkan ketentuan nash yang ada, yang bersifat qath'i bukan didasarkan pada konsep kemaslahatan. Apalagi jika kemaslahatan itu adalah kemaslahatan yang disangkakan. Sebab tidak mungkin Allah swt menetapkan sesuatu yang berbahaya bagi hamba-hambaNya dan tidak bermanfa'at bagi mereka ${ }^{46}$.

\section{Kesimpulan}

Berdasarkan pembahasan di atas, maka dapat disimpulkan bahwa waktu pelaksanaan ibadah haji yang ada sekarang ini bersifat baku sehingga tidak mungkin ditetapkan pelaksanaan ibadah haj di luar waktu yang ditetapkan itu. Hal ini didasarkan pada berbagai dalil yang ada, baik yang terdapat dalam al-Qur'an maupn Hadits. Memang jika dilihat secara parsial, maka ayat-ayat dan hadits yang ada tidak menunjukkan adanya suatu ketentuan yang bersifat qath'i, bahkan cenderung saling bertentangan. Namun ketika digabungkan, maka dalil-dalil tersebut menunjukkan kalau waktu pelaksanaan ibadah haji itu sifatnya qath'i. Ke-qath' $i$-an ini dapat

45 Masdar F. Masudi, Agama Keadilan: Risalah Zckat (Pajak) dalam Islam, (Jakarta: P3M, 1991), hlm. 97.

${ }^{46}$ Yusuf al-Qardhawi, Pedoman Bernegara dalam Perspektif Islam, pent: Kathur Suhardi, (Jakarta: Pustaka al-Kautsar, 1999), cet. I, hlm. 144. 
dilihat dari sisi kandungan yang dimaksud oleh dalil-dalil tersebut maupun melalui fakta sejarah yang ada, yang menunjukkan kalau waktu pelaksanaan haji itu memang benar-benar tidak dapat diubah, ditambah maupun dikembangkan lagi dari waktu yang ada sekarang ini.

Kaidah masyaqqat, tidak dapat dijadikan dasar untuk mengembangkan waktu pelaksanaan ibadah haji dengan alasan adanya kesulitan yang luar biasa yang menimpa para jam'ah haji sehingga menimbulkan berbagai tragedi kemanusiaan yang sering menimpa jama'ah haji itu bisa disebabkan oleh ketidakpahaman atau ketidakpatuhan para jama'ah itu sendiri atas berbagai peraturan yang sudah ditetapkan oleh panitia haji. Mungkin akan berbeda ketika para jama'ah haji mematuhi peraturan-peraturan tersebut.

\section{Daftar Pustaka}

al-Asyqar, Muhammad Sulaiman, Af'al al-Rasul wa Dilalatuha 'Ala alAhkam al-Syar'iyyah, Beirut: Mu'assasah al-Risalah, 1992, Cet. III.

al-Ayyubi, Muhammad Hisyam, al-ljtihad wa Muqtadhayat al-Ashr, Beirut: Dar al-Fikr, t.th.

al-Ma'afiri, Hisyam Abu Muhammad Abdul Malik bin Hisyam, Muskhtashar Sirah Ibnu Hisyam, Cairo: al-Ahkam al-Tijariyah, 1999.

al-Qardhawi, Yusuf, 'Awamil al-Sa'ah wa al-Muru'ah fi al-Syari'ah alIslamiyah, Kairo: Dar al-Shahwah, 1985.

al-Qardhawi, Yusuf, Pedoman Bernegara dalam Perspektif Islam, pent: Kathur Suhardi, Jakarta: Pustaka al-Kautsar, 1999, Cet. I.

al-Qurtubi, Muhammad bin Ahmad bin Abu Bakar al-Farah, al-Jami' li Ahkam al-Qur'an, Beirut: Dar al-Sya'b, $1372 \mathrm{H}$.

al-Sajastani, Sulaiman bin al-Asy'at Abu Daud, Sunan Abu Daud, Beirut: Dar al-Fikr, t.th..

al-Syatibi, Abu lshaq Ibrahim al-Lakhmi al-Gharnati, al-Muwafaqat fi Ushul al-Ahkam, ed: Sayyid Muhammad al-Hadhar Husain, Beirut: Dar alFikr, t.th.

al-Syaukani, Muhammad bin Ali, Nail al-Authar, Beirut: Dar al-Khair, 1998, Cet. II.

al-Thabari, Muhammad bin Jarir bin Yaitd bin Khalid, Tafsir al-Thabari, Beirut: Dar al-Fikr, 1405 H. 
al-Zuhaili, Wahbah, Ushul al-Fiqh al-Islami, Beirut: Dar al-Fikr, 1996, Cet. VI.

Dahlan, Abdul Aziz (ct, al), Ensiklopedi Hukum Islam, Jakarta: Ichtiar Baru Van Hoeve, 1996.

Dahlan, Abdurrahman, Kaidah-Kaidah Penafsiran al-Qur'an, Bandung: Mizan, 1997, cet. I.

Dharma, S. Satya, Haji Kita; Fakta dan Problem Penyelengaran Haji Di Indonesia 1999-2000, Jakarta: Asosiasi Wartawan Muslim Indonesia, 2000, Cet I

Djamil, Fathurrahman, Filsafat Hukum Islam, Jakarta: Logos Wacana Ilmu, 1999.

Faris, Ahmad Ibnu, Mu'jam Maqayis al-Lughah, Beirut: Dar al-Kutub alIlmiyyah, 1999, cet. I.

Hadi, Abdul Mahdi bin Abdul Qadir bin Abdul, al-Radd 'ala Liwa' Muhammad Syibl fi Inkar Yaum 'Arafah, Cairo: Ruz Yusuf, Majalah al-Azhar, $1420 \mathrm{H}$.

Hanafi, Muchlis M., Waktu Ibadah Haji Tidak Perlu Ditinjau Kembali, Jakarta: Majalah Islamia, thn.I, no.2, edisi. Juni-Agustus, 2004.

Hassan, Husein Hamid, Nadzariyyat al-Maslahah fi al-Fiqh al-Islami, Beirut: Dar al-Nahdhah al-Arabiyah, 1971.

Kompas, Kolom Fokus, Musibah-musibah itu, Edisi Sabtu, 7-2-2004.

Madkur, Muhammad Salam, al-Madkhal al-Fiqh al-Islami, Cairo: Maktabah al-Qawwiyyah li al-Nasyr wa al-Thaba'ah, 1964.

Mas'udi, Masdar F., Kolom Kajian, Bisa Berhaji dalam Waktu Tiga Bulan, Indo Pos, Edisi minggu, 18-1-2004.

Masudi, Masdar F., Agama Keadilan: Risalah Zakat (Pajak) dalam Islam, Jakarta: P3M, 1991.

MUI, Kumpulan Fatwa Majelis Ulama Indonesia, Jakarta: Pustaka Panjimas, 1984.

Qadir, Muhammad al-Arusi Abdul, Af'al al-Rasul wa Dilalatuha Ala alAhkam, Jeddah: Dar al-Mujtami' li al-Nasr wa al-Tauzi', 1991, Cet. II.

Sanu, Qutub Musthafa, Mu'jam Mushthalah Ushul al-Fiqh, Beirut: Dar alFikr, 2000, cet I.

Shihab, Umar, Kontekstualitas al-Quran, Jakarta: Penamadani, 2004, cet. $\Pi$ 
84 | FOKUS : Jurnal Kajian Keislaman dan Kemasyarakatan Vol. 5, No. 1, 2020

Syarifuddin, Amir, Garis-Garis Besar Fiqh, Jakarta: Prenada Media, 2003.

Thoyar, Husni, Ta'abbudi dan Ta'aqquli dalam Pandangan al-Syatibi, dalam jurnal Kordinat, volume: VI, no: 2, Oktober 2004. 